\title{
Mengisi Liburan Semester dengan 5M
}

\author{
Mohammad Tohir \\ Mahasiswa S2 Pendidikan Matematika FKIP Pascasarjana Universitas Jember \\ Guru SMP Negeri 2 Jember \\ Email: $160220101001 @$ students.unej.ac.id
}

\begin{abstract}
Liburan semester merupakan waktu yang ditunggu-tunggu oleh mayoritas mahasiswa. Karena liburan semester menjadi waktu yang tepat untuk melepas penat setelah rutinitas kuliah yang padat, mulai dari pembelajaran di kelas, tugas kuliah yang menumpuk, aktivitas organisasi, sampai tugas kantor/instansi masing-masing. Hal ini tidak heran apabila mahasiswa mengalami tingkat stress yang tinggi jika tidak dibarengi dengan liburan. Mayoritas mahasiswa selama liburan biasany pulang kampung atau menghabiskan waktu dengan keluarga, ada juga yang pergi piknik, berwisata untuk refresing, bahkan ada juga yang cuma tetap dirumah sambil main game. Akan tetapi jikalau kita mengisi liburan dengan hal-hal yang posirif akan lebih baik dan bermakna bagi kita, masyarakat, bangsa dan negara. Berikut lima kegiatan yang dapat kita lakukan dalam mengisi liburan semester yang penulis rangkum dalam $\mathbf{5 M}$ : yaitu (1) Meningkatkan Keimanan dan Ketakwaan kepada Tuhan yang Maha Esa, (2) Mengasah Skill Akademik maupun Non-akademik, (3) Menghabiskan Waktu Bersama Keluarga/Famili/Teman Dekat, (4) Mengembangkan Karir, (5) Membangun Koneksi atau Relasi yang Baik. Berikut uraian selengkapnya:
\end{abstract}

(1) Meningkatkan Keimanan dan Katakwaan kepada Tuhan yang Maha Esa

a. Menghafal kitab suci Al-Quran atau memperbanyak bacaan kitab suci Al-Quran Bagi umat muslim menghafal kitab suci Al-Quran merupakan kegiatan ibadah yang sangat mulya dan bermanfaat didunia dan akhirat. Manfaat di dunia, otak kita akan terpacu membentuk sinaps dan jaringan yang lebih kompleks sehingga meningkatkan kemampuan berfikir. Dari Abi Umamah ra. Ia berkata: "Aku mendengar Rasulullah SAW bersabda, 'Bacalah olehmu Al-Quran, sesungguhnya ia akan menjadi pemberi syafaat pada hari kiamat bagi para sahabatnya". (HR Muslim). Yang dimaksud sahabat Al-Quran adalah orang-orang yang senantiasa berinteraksi dengannya. Baik itu membaca, menghafal, mentadabburi, mengajarkan dan sebagainya. Orang-orang yang dekat dengan Al-Quran ini kelak pada hari penghitungan amal akan mendapat 'bantuan' dari Al-Quran. Ia akan datang menjadi saksi bagi kita. Sedangkan keuntungan ketika di akhirat, kita akan dimuliakan oleh Allah SWT. berdasarkan kadar hafalan kita.

b. Berangkat umroh ke tanah suci

Mengisi liburan semester dengan melakukan ibadah umroh ke tanah suci. Ibadah umroh ini mungkin hanya dapat dilakukan oleh sebagian orang saja, karena memerlukan biaya yang besar bagi sorang mahasiswa. Akan tetapi, bagi teman-teman mahasiswa yang sudah memiliki cukup uang layak seakali untuk melakukan alternatif ini sehingga dapat menemukan suasana dan sentuhan spiritualitas yang lebih tinggi dan mendalam.

c. Melakukan ziarah wali

Sunan Ampel adalah orang yang pertama kali melakukan ziarah ke makam para wali. Yaitu makam kakek dan ayahnya,kemudian makam pamannya. Dalam berziarah,beliau mengajak murid-muridnya. Sepeninggal Sunan Ampel, murid-muridnya melanjutkan ziarah ke makam-makam para wali yang lebih dahulu meninggaldunia. Ziarah muridmurid Sunan Ampel itu kemudian hari dilanjutkan oleh ummat Islam sekarang ini. Salah satu manfaat ziarah yang disampaikan oleh Sunan Ampel adalah ziarah akan menjadikan seseorang mengenal kematian. Sehingga semasa hidupnya akan selalu ingat kepada Allah dan tidak akan menjalankan maksiat serta berprilaku sombong di muka bumi. Karena pada akhirnya manusia itu tidak berdaya setelah menghadapi maut.

d. Mengikuti kegiatan-kegiatan pengajian, majelis taklim/muslimatan, majelis dzikir, dan atau melakukan kegiatan keagamaan lain.

Kita sebagai umat yang beragama, tentunya harus selalu melakukan kegiatan yang dapat menambah keimanan dan ketakwaan kita kepada Tuhan Yang Maha Esa. Karena ketika kita melakukan keagamaan, maka wawasan dan pengetahuan kita akan bertambah tentang agama yang kita anut. Jika kegiatan-kegiatan seperti inilah yang dapat kita lakukan selama liburan semester, tentunya akan lebih baik dari pada kita melakukan halhal yang kurang bermanfaat. 


\section{(2) Mengasah Skill Akademik maupun Non-akademik}

a. Mengikuti kursus bahasa asing

Penguasaan bahasa asing sangat berguna dalam memasuki era globalisasi dan menyambut MEA (Masyarakat Ekonomi ASEAN), Indonesia akan menjadi melting pot bagi masyarakat dari berbagai negara dengan latar belakang bahasa dan budaya yang berbeda. Apabila kita belum memiliki rencana yang pasti dalam mengisi liburan semesteran, mungkin akan lebih baik jika kita mempertimbangkan untuk belajar bahasa asing, baik itu bahasa inggris maupun bahasa asing lainnya, misalkan bahasa Arab, Jerman, Perancis, Jepang, dan lainnya. Dalam mengambil kursus, kita dapat mengambil kursus di lembaga tertentu yang resmi dan terpercaya, atau ortodidak dengan buku dan beberapa program gratis di internet.

b. Melakukan riset tertentu berdasarkan keahliannya masing-masing atau menjadi assisten pada proyek penelitian dosen.

Bagi mahasiswa jurusan pendidikan yang sudah mengajar baik di instansi formal maupun non formal dapat melakukan penelitian tentang hasil ujian semester ganjil entah dianalisis ataupun mengetahui tingkat keberhasilan siswa dalam belajar selama semester ganjil atau melakukan penelitian lainnya tentang hasil belajar atau tentang evaluasi penggunaan model/medai pembelajaran selama semeseter ganjil dan dapat juga mempersiapkan rencana pengajaran pada semester genap. Sedangkan bagi mahasiswa yang selain jurusan pendidikan dapat melakukan surve di tempat-tempat tertentu berdasarkan jurusan masing-masing misalkan jurusan pertanian yaitu melakukan surve kepada para petani tentang perbedaan hasil pertanian padi pada musim hujan dengan musim kemarau atau surve lainnya. Bagi mahasiswa yang jurusan teknik dapat melakukan surve ditempat deller tertentu atau ditempat proyek pembangunan. Jika memungkinkan sebagian mahasiswa dapat membantu proyek penelitian yang dilakukan oleh dosennya masing-masing. Menjadi assisten dosen pada proyek penelitiannya merupakan kesempatan langka dan sangat sedikit mahasiswa yang mendapatkan kesempatan tersebut.

c. Menjadi guru bimbingan belajar atau guru les private

Bagi mahasiswa yang suka bersosialisasi dan berbagi ilmu dengan sesama, pada liburan semster biasanya dimanfaatkan untuk mengaplikasikan ilmu mereka kepada masyarakat di sekitar tempat tinggalnya maupun secara online. Mulai dari menjadi tutor bimbingan olimpiade, membuka bimbingan les bahasa inggis secara gratis di rumahnya untuk anakanak tetangga, sampai pada membantu mengajar nagji di TPA (Tempat Pengkajian AlQur`an) setempat.

d. Mengikuti seminar/pelatihan/workshop

Salah satu kegitan yang mungkin kita dapat lakukan pada saat liburan semester adalah mengikuti seminar/pelatihan/workshop. Jika acara ini ada selama liburan, maka hal ini merupakan kesempatan kita untuk menambah ilmu dan memperluas pengalaman.

e. Mengikuti program semester pendek

Bagi mahasiswa yang masih memiliki nilai kurang memuaskan dapat menempuh semester pendek pada saat liburan, program semester pendek ini tentu nantinya dapat membuat lulus lebih cepat dari seharusnya karena mengambil mata kuliah lebih cepat dari teman-temanmu yang tidak mengikuti program semester pendek.

f. Mempersiapkan diri untuk semester depan atau berikutnya

Kita sebenarnya dapat memanfaatkan waktu liburan ini untuk mempersiapkan diri dalam menghadapi semester berikutnya, misalnya dengan mulai mempelajari berbagai materi yang akan diajarkan. Dengan mempersiapkan diri ini, tentu kita akan lebih siap tempur menghadapi semester yang akan datang.

g. Mengikuti kursus olahraga (selain mahasiswa jurusan olahraga)

Selain kita mengikuti kursus bahasa asing, akan lebih baik jikalau kita mengikuti kursus olahraga atau minimal olahraga teratur berdasarkan pengalaman kita. Hal ini akan bermanfaat bagi kesehatan tubuh kita, karena kalau kita teratur berolahraga akan membatu tubuh kembang tubuh kita pada yang lebih baik dan tubuh kita menjadi sehat. Akal yang sehat tergantung pada jasmani yang sehat pula, kalimat seperti inilah yang sering kita dengan ketika sekolah.

h. Mulai membuat atau membangun blog pribadi

Mempunya blog pribadi merupakan salah satu cara kita untuk menyalurkan pengalaman kita atau ide kita untuk disalurkan kepada masyarakat, bangsa dan negara demi majunya 
dunia pendidikan indonesia atau hasanah bangsa. Kepemilikan personal blog ini juga menjadi salah satu nilai pembeda yang positif bagi seorang kandidat dibanding kandidat lainnya yang hanya bermodalkan ijazah dan sertifikat saja. Hal ini tentu saja ini membuka kesempatan lebih lebar untuk meniti karier yang cemerlang. Sejak tahun 2013 Penulis artikel ini sudah memiliki dan mengelola di dua blog umum yang berbeda (https://matematohir.wordpress.com/ dan http://olimattohir.blogspot.co.id/) dan ada satu blog lagi, yaitu blok lokal / kampus (http://tohir.web.unej.ac.id/). Salah satu keuntungan dalam memiliki blog pribadi adalah memperbanyak teman diskusi dan shering ide tentang masalah dunai pendidikan serta masalah lainnya. Apabila blog pribadi tersebut dikelola dengan profesional dan diisi dengan konten berkualitas dan diupdate kontennya secara rutin dan kontinu, maka hal itu bisa menjadi sarana menghasilkan uang, entah melalui jalan Google adsense, affiliate program atau yang lainnya. Kesempatan yang besar dalam membuat dan mengelola blog pribadi adalah pada saat liburan semeseter ini.

\section{(3) Menghabiskan Waktu Bersama Keluarga/Famili/Teman Dekat}

a. Berlibur ke tempat wisata (jika memungkinkan ke tempat yang belum pernah dikunjungi)

Berlibur ke tempat wisata ini yang kebanyakan bakal dilakukan oleh para mahasiswa pada umumnya. Kegiatan seperti ini merupakan kegiatan yang sangat bagus untuk mengisi waktu liburan kita. Kegiatan ini bisa kita lakukan dengan keluarga, maupun dengan famili atau teman-teman kuliah. Liburan bersama ini selain bagus untuk merefresh pikiran setelah penat dengan segunung tugas dan laporan, juga bagus untuk mengakrabkan diri dengan teman maupun keluarga yang mungkin selama kuliah terlalu sibuk dengan tugas kuliah yang menumpuk.

b. Mendesain isi rumah menjadi lebih apik dan nyaman

Kegiatan mendesain rumah merupakan suatu kegiatan yang sehat, karena rumah yang sehat akan mendukung kita untuk selalu berbuat yang positif pula dengan kata lain "rumahku adalah surgaku".

c. Melakukan silaturahmi kepada sanak-famili

Kegiatan silaturahmi kepada sanak-famili tidak harus menunggu hari raya tiba, kegiatan ini bisa dilakukan pada saat liburan tiba untuk mempererat hubungan dengan sanakfamili.

\section{(4) Mengembangkan Karir}

a. Membaca dan Menulis buku atau novel

Membaca buku atau novel tertentu yang dapat mengambangkan ide kita merupakan hal yang positif apalagi sampai bisa mengusun buku matapelajaran untuk digunakan di instansi masing-masing. Liburan semester yang cukup panjang, sangat tepat dimanfaatkan untuk mengasah dan memunculkan kemampuan menulis kita. Menulis buku atau novel itu tidak sesulit seperti yang kita bayangkan. Jika kita benar-benar rajin membaca, ada kemuan kuat dan sungguh-sungguh, hil ini sudah menjadi modal utama untuk menulis buku atau novel. Syrata yang tidak kalah pentingya juga adalah asal berani mencoba dan sering dilatih, maka kemampuan menulis kita semakin lama akan semakin bagus dan baik.

b. Mencoba membuka bisnis/jasa atau mengembangkan jiwa wirausaha dengan memulai bisnis

Masa kuliah adalah masa yang tepat untuk mengembangkan jiwa wirausaha yang kita miliki. kita bisa membangun bisnis sendiri, maupun bersama teman-teman kita. Siapa tahu, bisnis yang kita cipatakan tidak hanya bermanfaat bagi diri kita sendiri, namun juga dapat bermanfaat bagi orang lain. Bisnis yang kita bangun juga bisa melalui online atau dan kita kita bisa mencoba juga berbisnis secara noline

c. Traveling sebagai backpacker

Melaukan kegiatan traveling sebagai backpacker merupakan salah satu alternatif kegiatan yang menarik untuk mengisi liburan semester kita. Sebagai backpacker sederhananya diartikan sebagai perjalanan liburan tanpa menggunakan jasa agen perjalanan atau angkutan travel. Semuanya diurus sendiri, mulai dari urusan transportasi, penginapan dan makan selama dalam perjalanan maupun di tempat tujuan. Berangkatnya bisa sendirian, berdua atau rombongan.

d. Mengembangkan hobi yang kita miliki atau mencoba hobi baru 
Liburan semester ini bisa menjadikan jadi waktu yang tepat untuk kita mengembangkan minat dan bakat yang kamu miliki. Karena selama kita menjalan perkuliahan mungkin kita tidak sempat untuk mengembangkan hobi yang kamu miliki karena segala kesibukan perkuliahan yang memusingkan kita.

\section{(5) Membangun Koneksi atau Relasi yang Baik}

a. Mengikuti program magang di sebuah perusahaan/instansi/lembaga tertentu

Mengikuti program magang di sebuah perusahaan/instansi/lembaga tertentu menjadi salah satu pilihan kegiatan mengisi liburan semester ini dan selanjutnya. Kegiatan ini artinya ikut bekerja di sebuah perusahaan tanpa atau dengan sedikit imbalan. Tujuan magang adalah untuk mencari pengalaman nyata di dunia kerja sambil menyerap ilmuilmu yang sering kali tidak diteukan di ruang kuliah. Magang biasanya dilakukan pada tempat atau perusahaan yang menjalankan ilmu sesuai dengan yang teman-teman tempuh. Misalnya, teman-teman kuliah di peternakan, maka biasanya magang dilakukan di perusahaan pembibitan atau di perusahaan penggemukan sapi. Jika teman-teman kuliah di jurusan pendidikan, maka biasanya magang dilakukan di TPA, PAUD atau TK.

b. Menjadi sukarelawan dalam bidang sosial

Menjadi sukarelawan dalam bidang sosial merupakan salah satu kegiatan yang jarang diminati, karena identik dengan pekerjaan yang berat dan tanpa bayaran. Akan tetapi, menjadi sukarelawan sebenarnya juga memberikan banyak manfaat bagi diri kita dan orang lain. Terutama bagi kita yang mengambil jurusan humaniora dalm perkuliahan kita.

c. Mengadakan/menghadiri pertemuan atau temua alumni dari instansi masing-masing Mengadakan temu alumni untuk masing-masing lembaga merupakan suatu kegiatan yang harus kita lakukan. Mengadakan temu alumni tentunya harus memilih waktu yang tepat, agar para alumni dapat harus seluruhnya. Liburan semester merupakan salah satu waktu yang tepat untuk mengadakan temu alumni. Karena biasa temu alumni merupakan ajang untuk selalu membangun koneksi arau relasi yang baik dengan sesama alumni dan lembanga tertentu. Menghadiri temu alumni tidak hanya mempererat hubungan dengan sesama alumni, akan tetapi juga bisa.

\section{Pustaka}

Tohir, Mohammad. 2016. Mengisi Liburan Semester dengan 5M. Online:

http://pasca.unej.ac.id/mengisi-liburan-semester-dengan-5m/ [20 Desember 2016] 